\title{
Clinical Therapeutic Strategy and Neuronal Mechanism Underlying Post-Traumatic Stress Disorder (PTSD)
}

\author{
Yasushi Yabuki and Kohji Fukunaga *(D) \\ Department of Pharmacology, Graduate School of Pharmaceutical Sciences, Tohoku University, \\ Sendai 980-8578, Japan \\ * Correspondence: kfukunaga@m.tohoku.ac.jp; Tel.: +81-22-795-6836; Fax: +81-22-795-683
}

Received: 10 July 2019; Accepted: 19 July 2019; Published: 24 July 2019

check for updates

\begin{abstract}
Post-traumatic stress disorder (PTSD) is characterized by an exaggerated response to contextual memory and impaired fear extinction, with or without mild cognitive impairment, learning deficits, and nightmares. PTSD is often developed by traumatic events, such as war, terrorist attack, natural calamities, etc. Clinical and animal studies suggest that aberrant susceptibility of emotion- and fear-related neurocircuits, including the amygdala, prefrontal cortex (PFC), and hippocampus may contribute to the development and retention of PTSD symptoms. Psychological and pharmacological therapy, such as cognitive behavioral therapy (CBT), and treatment with anti-depressive agents and/or antipsychotics significantly attenuate PTSD symptoms. However, more effective therapeutics are required for improvement of quality of life in PTSD patients. Previous studies have reported that $\omega 3$ long-chain polyunsaturated fatty acid (LCPUFA) supplements can suppress the development of PTSD symptoms. Fatty acid binding proteins (FABPs) are essential for LCPUFA intracellular trafficking. In this review, we have introduced Fabp3 null mice as an animal model of PTSD with impaired fear extinction. Moreover, we have addressed the neuronal circuits and novel therapeutic strategies for PTSD symptoms.
\end{abstract}

Keywords: post-traumatic stress disorder; fatty acid binding protein 3; calcium/calmodulindependent protein kinase II; ramelteon

\section{Introduction}

Post-traumatic stress disorder (PTSD), a profound public health issue, is most often induced by distressing events. During a lifetime, a majority of the population, $60.7 \%$ of men and $51.2 \%$ of women, may be exposed to traumatic events that have the potential to trigger the development of PTSD [1,2]. While previous studies have estimated the lifetime prevalence of PTSD in United State as 6.1-6.8\%, and in Japan as 1.3\% [3-5], 16.7\% of the individuals exposed to the terrorist attack of September 11, 2001, experienced an onset of PTSD [6]. In addition, 5.7\% of the survivors from the tsunami caused by The Great East Japan Earthquake on March 11 showed post-traumatic stress reactions [7]. Development and retention of PTSD are observed not only in the victims of disasters, but also in the rescue workers [8-10]. In the pathogenesis of PTSD, the fear memories are aberrantly consolidated, while the fear extinction fails to function [11]. Impaired fear memory consolidation and extinction triggers develop nightmares and flashbacks in patients with PTSD [2,11,12]. Patients with PTSD often show cognitive impairment, attention and/or learning deficits [13,14], which reduce the quality of life (QOL). According to clinical and animal studies, emotion- and fear-associated neuronal circuits are related to the development and retention of PTSD symptoms $[11,15,16]$ and several therapeutics have been recommended $[1,12,17,18]$. However, mechanisms underlying enhanced susceptibility to impaired fear memory consolidation and extinction are not clear, and therefore, there are limited effective therapeutic approaches. 
We, here in this review, discuss the neuronal circuits and a novel therapeutic strategy for PTSD symptoms. Moreover, we introduce a PTSD animal model to evaluate the efficacy of therapeutics in future investigations.

\section{Neuronal Circuits in PTSD Symptoms}

Animal studies suggest the crucial brain regions associated with PTSD symptoms as the prefrontal cortex (PFC), anterior cingulated cortex (ACC), amygdala, and the hippocampus, which are involved in the formation and retrieval of emotional and fear memory [19-21]. Destruction of the medial PFC (mPFC) by electrolytic lesion has shown to impair recall of fear extinction in rats [22]. The elevated neuronal firing rate in the infralimbic $\mathrm{mPFC}$ has been correlated with spontaneous recovery of freezing after the fear extinction, and short-term electric stimuli in infralimbic MPFC has shown to facilitate fear extinction memory in rats [19]. The infusion of $\gamma$-aminobutyric acid (GABA) receptor agonist, muscimol, into rat amygdala fails to acquire and consolidate fear memory [21]. Pharmacological lesions and inactivation in rat hippocampus have shown to block contextual fear memory formation [23,24]. Moreover, these brain regions are connected and regulated with each other $[20,25,26]$. In another study, the inactivation of basolateral amygdala (BLA) by infusion of muscimol decreased the neuronal activity in pyramidal neurons, as well as the fear conditioning tone response in rat prelimbic $\mathrm{mPFC}$. Inversely, the inhibited ventral hippocampal activity enhanced the activity of interneurons and then promoted the tone response in rat prelimbic MPFC [25]. Optogenetic analyses have also indicated that the mouse BLA-mPFC synaptic inhibition impairs fear memory retention and facilitates fear extinction [27]. Therefore, neuronal connections between PFC, amygdala, and hippocampus may have an essential role in normal fear consolidation and extinction.

In addition, human studies also support the above discussed neuronal circuit in PTSD patients. The magnetic resonance imaging (MRI) studies have demonstrated reduced volumes of hippocampus and ACC in the brain of PTSD patients [28-32]. Functional MRI researches have also defined excessive activity in the amygdala, while hypofunction in both the MPFC and ACC in patients with PTSD when they are exposed to fear condition [33-37]. In contrast, several groups have reported that the activities of both the amygdala and ACC are higher in patients with PTSD than that in healthy subjects [38,39]; thus, the neuronal activity of ACC in PTSD is controversial. Brain blood flow is significantly decreased in the mPFC of patients with PTSD exposed to traumatic stimuli, whereas in non-PTSD subjects, it is elevated in ACC, indicating a negative relationship between $\mathrm{MPFC}$ and ACC [31,40]. In addition, synchronous neuronal activities between ACC and BLA are essential for a normal fear response [41,42]. Previous reports suggest that neuronal activities in the PFC, including $\mathrm{MPFC}$ and ACC, negatively function in BLA, thereby suppressing exacerbated fear response and anxiety [43-45]. According to clinical therapy reports, veterans with PTSD, who had been deployed to Iraq or Afghanistan, either showed improvement or normalization of the hyperactive amygdala and hypofunctional ACC on exposure therapy among individuals with PTSD during an affective Stroop response test [46,47]. Oxytocin treatment alleviates the impairment of the working memory, and concomitantly increases connectivity between the dorsolateral PFC and ACC in patients with PTSD [48]. Moreover, both pharmacological and psychological therapies have been reported to increase the volumes of the hippocampus and/or ACC, in association with the improvement of PTSD symptoms [49-53]. Taken together, these observations suggest that aberrant neuronal activities in PFC, ACC, amygdala, and hippocampus may be one of the reasons underlying development and retention of PTSD symptoms.

\section{Clinical Therapeutics for Patients with PTSD}

\subsection{Psychological Therapy for PTSD Symptoms}

According to National Institute for Clinical Excellence study (2005), Kar (2011) and Lee et al. (2016), psychological therapies, such as cognitive behavioral therapy (CBT) are recommended as the first-line therapy for PTSD symptoms [54-56]. CBTs, as represented by cognitive processing therapy, stress 
inoculation training, and written exposure therapy significantly improve PTSD symptoms [18,57-61]. Eye movement desensitization and reprocessing also attenuates PTSD symptoms [18,62-64]. The other types of psychological therapy highlight the effectiveness of imagery rehearsal therapy (IRT) and Seeking Safety (SS) in PTSD symptoms. However, supporting evidence for such therapies are inconclusive $[18,65,66]$. PTSD subjects undergoing CBTs have demonstrated better QOL before the treatment $[61,67]$. On the other hand, no differences in QOL have been observed between pre- and post-treatment with eye movement desensitization and reprocessing in patients with PTSD [18,62].

\subsection{Pharmacological Therapy for PTSD Symptoms}

Since imperative traumatic incidents, such as the terrorist attack and massive earthquake occur unexpectedly, and possess a strong potential to develop PTSD in the victims [6,7], pharmacological therapies are also crucial for the relief of PTSD symptoms. Clinical studies have demonstrated an improvement in PTSD by selective serotonin reuptake inhibitors (SSRIs), serotonin and noradrenaline reuptake inhibitor (SNRI), antipsychotics, and other drugs as listed in Table 1. SSRIs, such as fluoxetine, paroxetine, and sertraline significantly relieve PTSD symptoms and partially improve QOL in the PTSD subjects [64,68-76]. Treatment with SNRI, venlafaxine, also attenuates the PTSD symptoms and shows improvement in QOL [76,77]. The effects of another type of antidepressants on PTSD symptoms are relatively weaker than those of SSRI and SNRI [78-81]. Atypical antipsychotics risperidone, olanzapine, and aripiprazole have also been effective for PTSD symptoms (Table 1) [82-87]; however, evidence for their therapeutic potential is limited [18]. Importantly, risperidone and olanzapine relieve the PTSD symptoms that are resistant to SSRI treatment $[84,86]$. The efficacies of calcium channel blocker, alpha blocker, anticonvulsant, and synthetic cannabinoid on PTSD symptoms have also been reported (Table 1) [88-94]. However, only paroxetine and sertraline have been approved by the U.S. Food and Drug Administration (FDA) for PTSD therapy [18], and these pharmacological treatments are extremely limited, due to their side effects. Therefore, more safe and effective therapeutics for PTSD are required.

Table 1. Effects of clinical drugs in patients with post-traumatic stress disorder (PTSD) and animal models of PTSD.

\begin{tabular}{|c|c|c|}
\hline Drug Treatment & Effects on PTSD Symptoms & Animal Models \\
\hline \multicolumn{3}{|l|}{ SSRI } \\
\hline Fluoxetine & Improvement $[64,68,69]$, Not effective [70] & Facilitation of fear extinction $[95,96]$ \\
\hline Paroxetine & Improvement $[71,72]$ & Prevention of PTSD symptoms reactivation [97] \\
\hline Sertraline & Improvement [73-75] & No effect on fear extinction [98] \\
\hline \multicolumn{3}{|l|}{ SNRI } \\
\hline Venlafaxine & Improvement $[76,77]$ & Facilitation of fear extinction [99] \\
\hline \multicolumn{3}{|l|}{ Anti-depressant } \\
\hline Mirtazapine & Improvement [80], Not effective [18] & Relief of fear response $[100,101]$ \\
\hline Bupropion & Not effective [81] & Relief of fear response [100] \\
\hline \multicolumn{3}{|l|}{ Antipsychotics } \\
\hline Risperidone & Improvement [82-84] & Facilitation of fear extinction [102] \\
\hline Olanzapine & Improvement $[85,86]$ & $\begin{array}{l}\text { Relief of fear response [102], deficits of fear } \\
\text { extinction [103] }\end{array}$ \\
\hline Aripiprazole & Improvement [87] & Facilitation of fear extinction [104] \\
\hline Sulpiride & No data & Facilitation of fear extinction [105] \\
\hline \multicolumn{3}{|l|}{ Other drugs } \\
\hline Gabapentin (Calcium blocker) & Improvement [88] & Relief of anxiety response [106] \\
\hline Prazosin (Alpha blocker) & Improvement $[89,90]$, Not effective [91] & $\begin{array}{c}\text { Relief of fear response [107], facilitation of fear } \\
\text { extinction [108] }\end{array}$ \\
\hline Topiramate (Anticonvulsant) & Improvement $[92,93]$ & Facilitation of fear extinction [109] \\
\hline Nabilone (Cannabinoid) & Improvement [94] & No data \\
\hline
\end{tabular}




\section{Animal Models of PTSD}

PTSD animal models are essential to evaluate the efficacy of drugs and to reveal the neurochemical basis underlying the development and retention of PTSD. Stress-induced animal models have been proposed as PTSD models in various studies $[110,111]$. Rats subjected to electric stimulations from two different contexts show an exacerbated sensitization of the fear response [110]. Single prolonged stress (SPS) combined with restraint for $2 \mathrm{~h}$, forced swimming for $20 \mathrm{~min}$, and exposure to ether anesthesia has shown to induce hypersensitivity of glucocorticoid negative feedback with abnormalities in hypothalamic-pituitary-adrenal (HPA) axis in male rats, similar to that of patients with PTSD [111]. Studies have demonstrated that the rats subjected to SPS show sleep abnormalities, aberrant anxiety, enhanced contextual fear response, and impaired fear extinction [112-115]. Moreover, rats subjected to predator-based psychosocial stress (PPS; subjected to unstable housing conditions [changing housing pair] for 31 consecutive days, followed by $1 \mathrm{~h}$ of immobilization and exposure to a cat on day 1 and day 11) or predator scent stress (PSS; $10 \mathrm{~min}$ of inescapable exposure to well-soiled cat litter) exhibit PTSD-like anxiety behaviors and impaired fear extinction, which have been proposed as the symptoms in animal models of PTSD [116-119]. Additionally, many studies have focused on the process of fear extinction following contextual or cued fear conditioning in the rodents as a predominant symptom of PTSD $[105,120]$. Most of the drugs with the reported clinical efficacy have demonstrated anti-PTSD characteristics in the rodent models (Table 1) [95-104,106-109], suggesting that the efficacy of drugs was initially evaluated using the above animal models. However, whether the chronic stress-induced models reflect PTSD pathology is still questionable, due to the lack of reproducibility in different studies.

To resolve these drawbacks, genetically modified animals have been useful in recent times for investigation of the neuronal mechanisms underlying the development and retention of PTSD. Several studies have indicated a relationship between PTSD symptoms and the serotonergic system. Serotonin 1A (5- $\left.\mathrm{HT}_{1 \mathrm{~A}}\right)$ receptor knockout $(\mathrm{KO})$ mice exhibit elevated anxiety-like behavior and fear retrieval [121-123]. On the other hand, lack of 5- $\mathrm{HT}_{1 \mathrm{~A}}$ receptor does not affect the process of fear extinction in mice [123], suggesting that $5-\mathrm{HT}_{1 \mathrm{~A}}$ receptor may be associated with fear memory retrieval and consolidation. Additionally, deletion of the gene coding for 5-HT transporter in mice impairs fear extinction recall and enhances PTSD-like behaviors following exposure to predator odor [124,125]. Deficiency of pheochromocytoma 12 ETS (E26 transformation-specific) factor (Pet-1) has shown to reduce the mRNA levels of tryptophan hydroxylase 2 (TPH2) and $5-\mathrm{HT}_{1 \mathrm{~A}}$ receptor, as well as the immunoreactivities of TPH2 and 5-HT in dorsal raphe [126]. Following the reduction of the serotonergic system in the mouse brain [126], Pet-1 KO mice show increased anxiety, aggressive behaviors, and elevated fear response $[127,128]$. Pet-1 KO mice also display delayed fear extinction learning, but it does not affect the process [128]. Moreover, fMRI analyses have revealed that the threat-induced amygdala hyperactivation is associated with human Pet-1 variant [128]. Thus, hypofunction of serotonergic systems may reflect one of the aspects of the PTSD symptoms. Additionally, other genetic models have been proposed. The brain-derived neurotrophic factor, Met allele, has been associated with PTSD and impairment of fear extinction learning in mice $[129,130]$. Conditional KO of the corticotrophin-releasing hormone receptor type- 1 gene in the limbic forebrain of mouse decreases remote associative and non-associative fear memory [131]. Mice with neuropeptide $\mathrm{Y}$ gene $\mathrm{KO}$ show potentiated acquisition of conditioned fear memory and impaired fear extinction [132]. Moreover, mice with overexpressed adult cholecystokinin receptor-2 display PTSD-like behavioral deficits when subjected to traumatic stimuli (foot-shocks) during puberty [133], suggesting that the interaction of genetic factor with the early environmental condition have an impact on the post-pubertal behavioral phenotype. These observations suggest that various genes are involved in altering the associated neuronal networks in PTSD; however, the molecular mechanism of fear extinction processing remains unclear. 


\section{Role of Long-Chain Polyunsaturated Fatty Acids (LCPUFAs) and Fatty Acid Binding Proteins (FABPs) in the Brain}

In the brain, LCPUFAs are an essential component of membrane phospholipids and important for brain development $[134,135]$. Aberrant metabolism of LCPUFAs has been reported in various psychiatric diseases. For example, levels of $\omega 3$ and $\omega 6$ LCPUFAs in the membrane of red blood cells are decreased in the schizophrenia subjects, while $\omega 3$ LCPUFA levels are reduced in the plasma of the autistic subjects [136-138]. Likewise, the concentration of $\omega 3$ LCPUFA is significantly decreased in the erythrocytes and plasma of PTSD patients [139]. Consistent with the observation, w3 LCPUFA supplementation has shown to prevent the development of PTSD and also reduce the PTSD symptoms after accidental injuries, including the Great East Japan Earthquake [140-142]. Studies have also demonstrated that the effect of $\omega 3$ LCPUFAs on the PTSD symptoms could be due to the elevation in the hippocampal neurogenesis $[140,141]$, since the hippocampus-dependent fear memory is closely associated with the activity of neurogenesis in mouse hippocampal dentate gyrus (DG) [143]. Indeed, w3 LCPUFA administration has shown to facilitate mouse and rat hippocampal neurogenesis $[144,145]$. Taken together, disturbances in the LCPUFA supplementation and metabolism may be associated with the PTSD symptoms.

FABPs, low molecular weight (14-15 kDa) proteins with twelve subtypes in most mammals, have a key role in the intracellular uptake, transport, and metabolism of LCPUFAs [146,147]. In the mouse and human brain, three types of FABPs, FABP3, FABP5, and FABP7 are primarily expressed [148]. While FABP5 and FABP7 are localized in the glial and neuronal stem/progenitor cells, FABP3 is expressed in the mature neuronal cells $[148,149]$. Lack of Fabp5 and/or Fabp 7 reduces the proliferation of neural stem cells in the mouse hippocampal DG [149], and Fabp7 null mice exhibit impaired emotional behaviors, including aberrant fear response, sensory motor dysfunction, and sleep disturbance [150,151]. We previously have demonstrated that FABP3 interacts with the dopamine D2 receptor long isoform (D2LR), and that deficiency of Fabp 3 reduces methamphetamine-induced sensitization and increases haloperidol-induced catalepsy, due to the dysfunction of dopamine D2 receptors [152,153]. Indeed, Fabp3 null mice are resistant to dopaminergic toxicity-induced parkinsonism [154]. Moreover, Fabp3, $F a b p 5$, and Fabp7 gene variants have been identified in patients with schizophrenia and autism spectrum disorder [155]. These observations suggest that dysfunction of FABPs in the brain is associated with the development of a psychiatric disorder.

\section{Impaired Fear Extinction Process in Fabp3 Null Mice}

To assess the fear process of extinction acquisition and extinction, a mouse is placed in a box with dark and light compartments, shown in Figure 1, and the step-through latency is recorded up to $300 \mathrm{sec}$ with or without electric shock (Day 1-4; Figure 1). No differences were observed during fear acquisition (Day 1-4) and retrieval (Day 5) between wild-type (WT) and Fabp3 null mice (Figure 2). WT mice showed normal fear extinction process from Day 12 to Day 35 gradually; however, Fabp3 null mice failed, suggesting that Fabp3 deficiency impairs fear extinction processing (Figure 2) [156]. Fabp3 null mice also exhibited cognitive impairment, increased daytime locomotor activity, which may reflect sleep disturbance, and anxiety behaviors [156,157], suggesting that Fabp3 null mice may display PTSD-like behaviors. Consistent with clinical investigations, the level of c-Fos, as an indicator of neuronal activity, was markedly elevated in the BLA of Fabp3 null mice one hour after the exposure of fear on Day 35 (Figure 3a,b) [156]. $N$-methyl- $d$-aspartate (NMDA) receptor signaling plays an essential role in fear response and c-Fos expression [158-160], and one of its major downstream targets calcium/calmodulin-dependent protein kinase II (CaMKII) phosphorylation levels are significantly reduced in the ACC and conversely elevated in the BLA of Fabp3 null mice as compared to WT mice [156], indicating hypofunction and hyperactivation in the Fabp3 null ACC and BLA, respectively. FABP3 is highly localized in the parvalbumin-positive GABAnergic neurons in mouse ACC, and the GABAnergic neuronal activities are elevated in the ACC of Fabp3 null mice, thereby attenuating glutamatergic neurotransmission [157]. Since the neuronal activity of ACC negatively regulates BLA 
neuronal activity and thus, suppresses overactivation of BLA neuronal circuit [43-45]. We, therefore, speculate that the hypofunction in ACC fails to suppress aberrant BLA neuronal activation during fear conditioning, thereby, impairing the process of fear extinction in Fabp3 null mice. These changes in the brain activities of Fabp3 null mice are likely to be similar to that observed in subjects with PTSD [33-39,46,47], and moreover, this is first report to demonstrate the relationship between FABP and PTSD, suggesting that Fabp3 null mice are useful genetic models to study the pathophysiology, and assess the effect of novel candidate drugs on PTSD symptom.

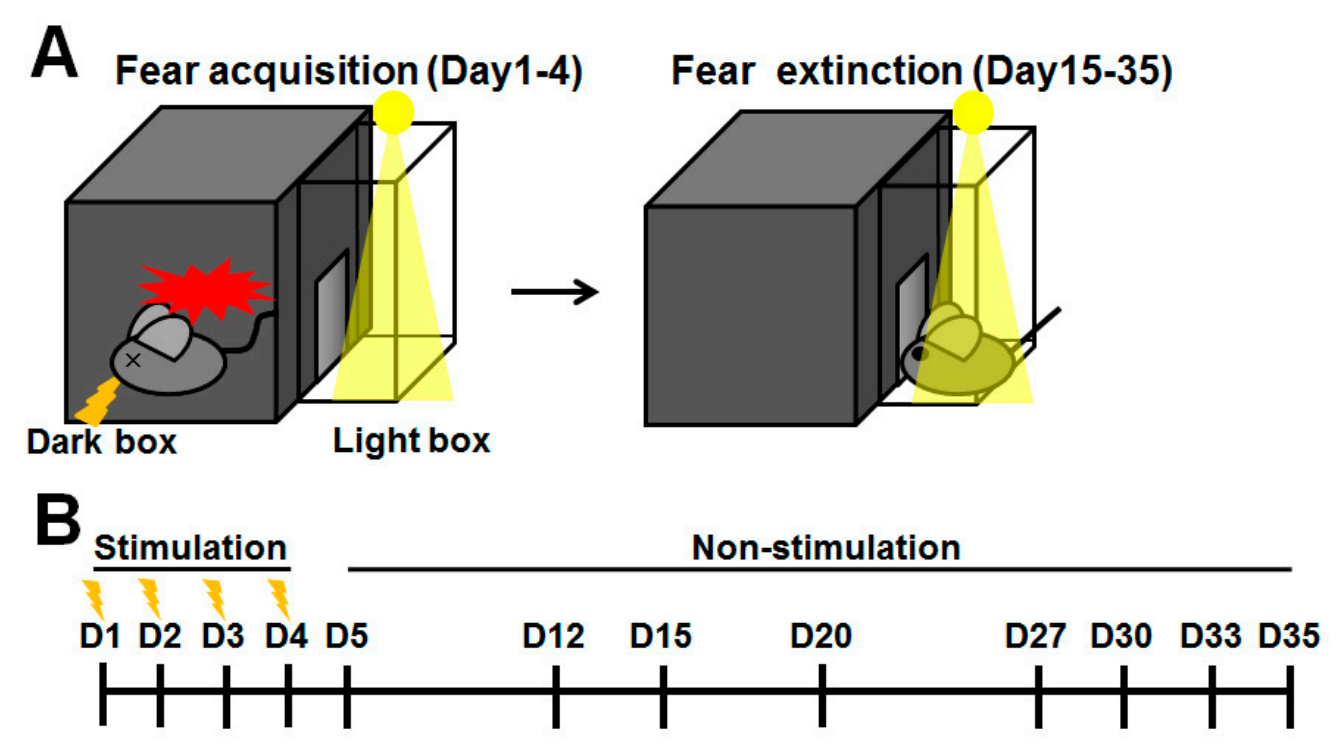

: Electric shock (0.5 mA for $3 \mathrm{~s})$

Figure 1. Experimental apparatus and design for evaluation of fear extinction. (A) Schematic diagram of contextual fear memory in passive avoidance task to evaluate fear extinction in the mouse. (B) Experimental schedule for assessment of fear extinction. Mice received an electric shock ( $0.5 \mathrm{~mA}$ for $3 \mathrm{~s}$ ) once a day for four consecutive days (fear acquisition). After that, the mouse was exposed to the light box, and step-through latency was measured without an electric shock (fear extinction). D: Day. 


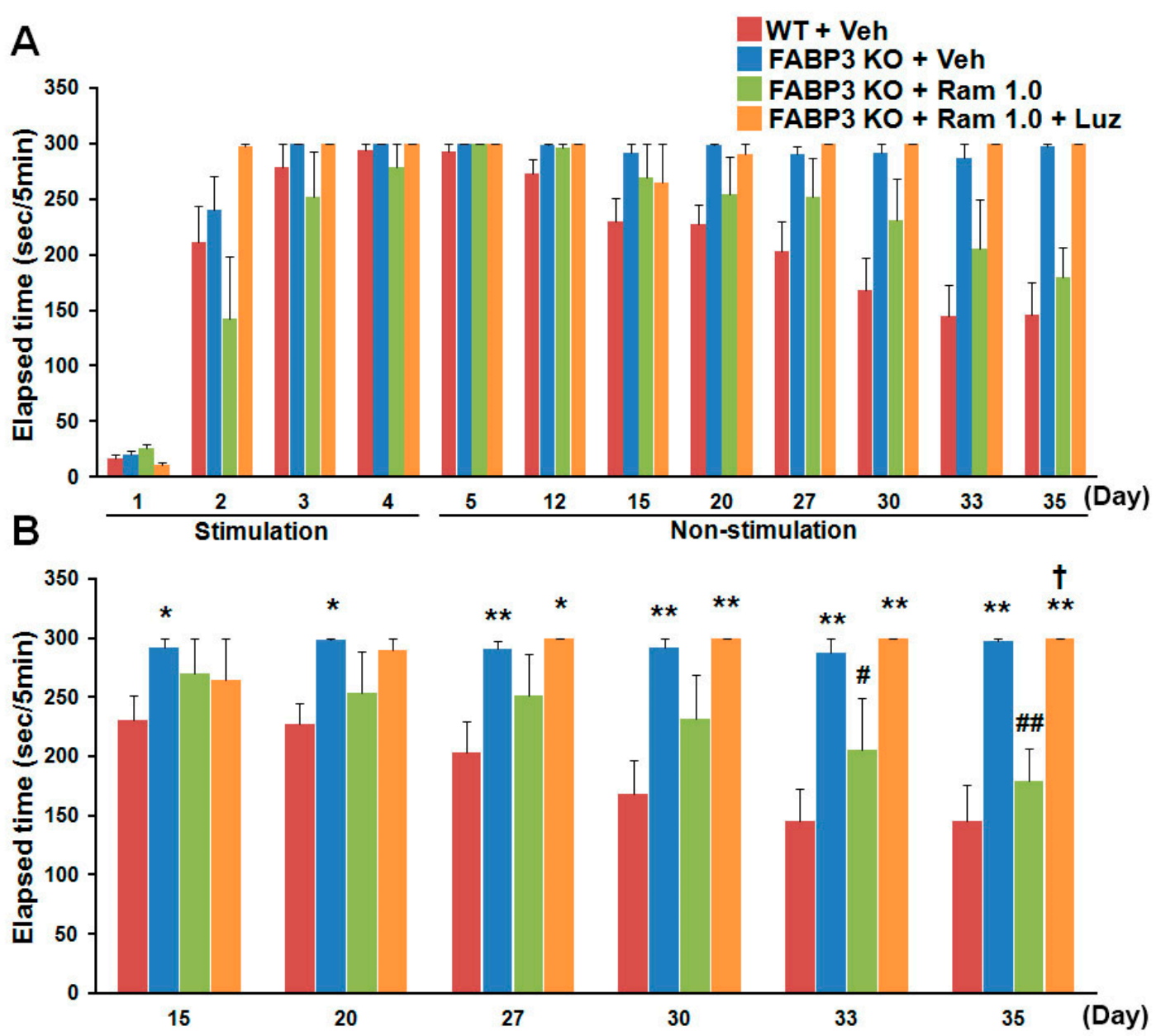

Figure 2. Impaired fear extinction processing in Fabp3 null mice. (A) Overview of fear responses as elapsed time during the acquisition (Day 1 to 4 ) and extinction phase (Day 5 to 35 ) ( $n=4-11$ per group). (B) Ramelteon $(1.0 \mathrm{mg} / \mathrm{kg}$, p.o.) repaired the impaired fear extinction process in Fabp3 null mice from Day 15 to 35 , an effect prevented by luzindole $(2.5 \mathrm{mg} / \mathrm{kg}$, i.p.) treatment $(n=4-11$ per group). Error bars represent SEM. ${ }^{*} p<0.05$ vs. vehicle-treated wild-type (WT) mice; ${ }^{* *} p<0.01$ vs. vehicle-treated WT mice; \# $p<0.05$ vs. vehicle-treated Fabp3 null mice; \#\# $p<0.01$ vs. vehicle-treated Fabp3 null mice; $\uparrow p<0.05$ vs. ramelteon $(1.0 \mathrm{mg} / \mathrm{kg}$, p.o.)-treated Fabp3 null mice. Luz, luzindole $(2.5 \mathrm{mg} / \mathrm{kg}$, i.p.) treatment; Ram 1.0 , ramelteon $(1.0 \mathrm{mg} / \mathrm{kg}$, p.o.) treatment; veh, vehicle treatment. Modified data derived from Reference [156]. 
A

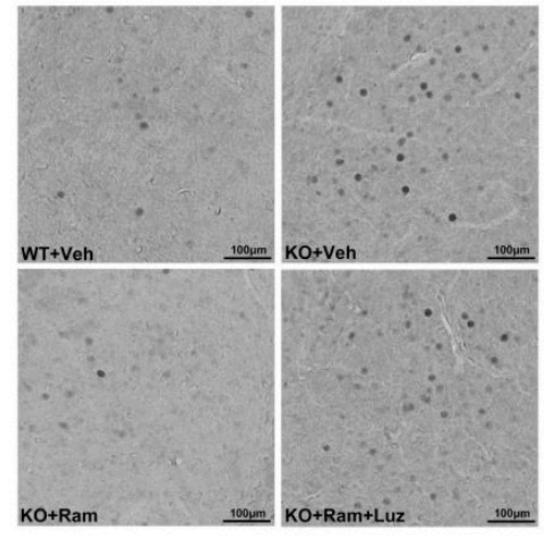

B

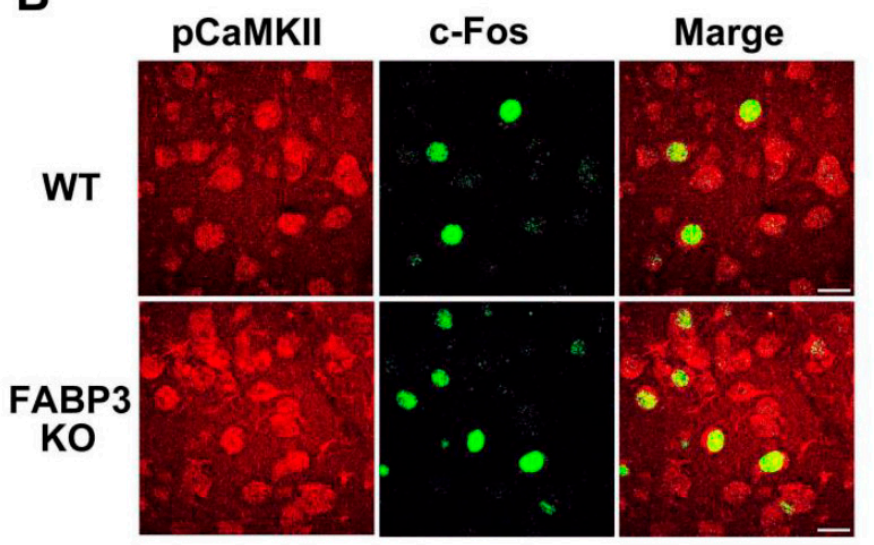

Figure 3. Aberrant c-Fos expression and CaMKII autophosphorylation levels in the basolateral amygdala (BLA) in Fabp3 null mice. (A) Representative images of BLA in each group of mice one hour after the extinction test on Day 35. The effect of ramelteon $(1.0 \mathrm{mg} / \mathrm{kg}$, p.o.) on the elevated level of c-Fos was antagonized by luzindole $(2.5 \mathrm{mg} / \mathrm{kg}$, i.p.) treatment in Fabp3 null mice. Scale bars: $100 \mu \mathrm{m}$. (B) Representative images of BLA in WT and Fabp3 null mice stained by phosphorylated CaMKII (red) and c-Fos (green). Increased c-Fos expression levels were observed in elevated autophosphorylation CaMKII-positive cells in BLA of Fabp3 null mice. Modified data derived from Reference [156].

\section{Potential Efficacy of Melatonin Receptor Agonist for PTSD Symptom}

Melatonin, a pineal hormone synthesized from serotonin, mediates circadian rhythms, sleep, mood, and cognition [161,162], and Huang et al. in their study observed that melatonin treatment facilitates fear extinction in naïve rats [163]. The melatonin receptor selective agonist, ramelteon, shows a 3- to 7-fold higher affinity and 5.5- to 9.6-fold greater potency for recombinant monkey and human MT1/MT2 receptors than that of melatonin and has been approved for insomnia in clinical therapy [164]. Therefore, we evaluated the effect of ramelteon on impaired fear extinction in Fabp3 null mice. Administration of ramelteon $(1.0 \mathrm{mg} / \mathrm{kg}$, p.o.) significantly relieved not only PTSD-like symptom, including impaired fear extinction, but also pathological changes in Fabp 3 null mice (Figure 2, Figure 3a). Melatonin receptor antagonist, luzindole $(2.5 \mathrm{mg} / \mathrm{kg}$, i.p. $)$ treatment prevents the effect of ramelteon in Fabp3 null mice (Figure 2, Figure 3a), suggesting that improvement by ramelteon may be due to activating the melatonin receptors. Importantly, melatonin MT1 and MT2 receptors are highly expressed in rodent PFC, including ACC, and are almost absent in the amygdala [165]. Since treatment with melatonin enhances the reduced CaMKII autophosphorylation levels in the hippocampal CA1 region and then improves the cognitive impairment in an animal model of autism [166], we suggest that ramelteon initially improves the decreased CaMKII activity (neuronal activity) in the ACC and in turn suppresses the elevated neuronal and CaMKII activities in the BLA, thereby, reversing the impaired fear extinction in Fabp3 null mice (Figure 4).

The previous report indicates that stimulation of Gi-coupled receptor triggers the G $\beta \gamma$-phospholipase $C \beta$ (PLC $\beta$ ) pathway and then elevates intracellular calcium levels by activating the inositol 1,4,5-trisphosphate receptors [167], suggesting one of the mechanisms underlying CaMKII activation by stimulation of melatonin receptors. In an ex vivo experiment, melatonin incubation in the brain slices enhanced the dendrite length, thickness, and complexity in the rat hippocampal neurons via CaMKII activation [168]. Glutamate $(10 \mu \mathrm{M})$ application failed to activate calcium signaling, including CaMKII in mouse cortical primary neurons on DIV 21, due to spontaneous firing; however, it significantly enhanced CaMKII autophosphorylation levels under melatonin $(5 \mu \mathrm{M})$ treatment [169]. Since levels of melatonin in the rat brain fluctuate with the circadian rhythm [170], CaMKII activation by glutamate application with melatonin treatment may reset the circadian rhythm in the suprachiasmatic nucleus in mice [170]. Additionally, NMDA receptor partial agonist, D-cycloserine, has demonstrated to facilitate fear extinction in animal models and patients with PTSD [171-173]. Taken together, 
hypofunction in ACC may fail to attenuate neuronal hyperactivity in BLA after contextual fear retrieval and in turn may impair fear extinction in Fabp3 null mice. Furthermore, ramelteon can antagonize the PTSD-like behaviors by MT receptor stimulation, and, hence, suppress the hyperactivation of BLA in Fabp3 null mice (Figure 4). Although the mechanism of action of ramelteon on CaMKII activation through the stimulation of Gi protein-coupled melatonin receptors is not clear, recent work on the protective functions of melatonin, especially in cognitive impairment implies the involvement of other kinases [174].

Although the clinical trial of patients experiencing PTSD with melatonin or ramelteon has not been conducted yet, reduced melatonin levels in the first $48 \mathrm{~h}$ after exposure to traumatic stress may be associated with a higher risk for PTSD [175]. Since the melatonin system plays an important role in sleep, cognitive function, pain, neuroimmunomodulation, stress response (HPA axis), circadian rhythm, and oxidative stress, all of which are affected in case of PTSD, upregulation of the melatonergic system could provide a potentially promising treatment strategy in the management of PTSD symptoms $[176,177]$. Here, we demonstrate the effect of ramelteon on PTSD-like behaviors in Fabp3 null mice. As ramelteon has been approved for treating sleep disturbance, the schedule of administration will be considered. In conclusion, we propose and hope that ramelteon is repurposed as a novel therapeutic for treating PTSD in the near future.
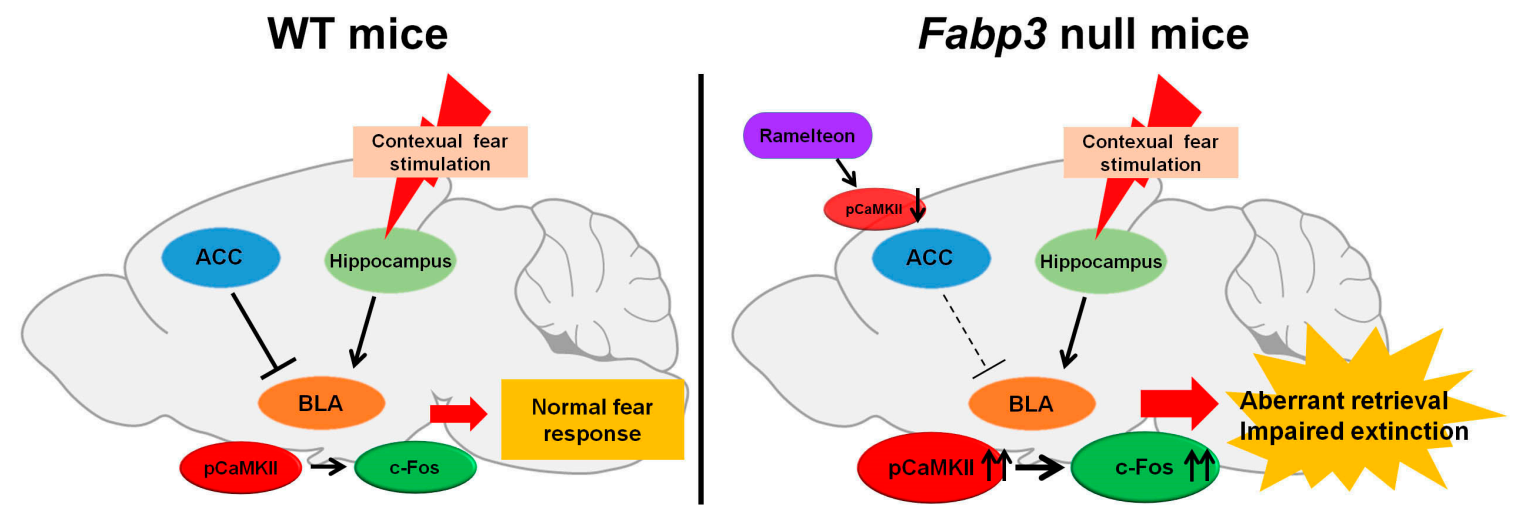

Figure 4. The hypothesis of neuronal circuits in the fear extinction in WT and Fabp3 null mice. (Left) Contextual fear memory is acquired in the hippocampus and then consolidated and retrieved in the BLA. The ACC negatively regulates neuronal activity in BLA, resulting in suppression of exacerbated fear retrieval and facilitation of fear extinction in WT mice. (Right) Hypofunction in the ACC fails to inhibit aberrant neuronal activity in the BLA, leading to the development of aberrant fear retrieval and impaired fear extinction in Fabp3 null mice. Ramelteon improves decreased neuronal activity in the ACC through stimulation of the melatonin receptors. Therefore, ramelteon improves the impaired fear extinction by suppressing hyperactivation of BLA in Fabp3 null mice (Right). Modified data derived from Reference [170].

\section{Conclusions}

In the present article, we have reviewed the predicted neuronal circuits and evidenced therapeutics in PTSD symptoms according to clinical and basic animal studies. Additionally, we introduce and discuss Fabp3 null mice as a useful animal model of PTSD to investigate the neurochemical basis of fear extinction processing. Similar to clinical observations, impaired neuronal activities in the ACC and BLA were found to be associated with PTSD-like behaviors in Fabp3 null mice, suggesting the potential role of FABP3 in PTSD. In another study, decreased levels of stress-related intracellular molecules, such as serum/glucocorticoid regulated kinase 1 and FK506 binding protein 5 were observed in the PFC of PTSD subject's postmortem, and also have been associated with fear response in rodents [44]. Melatonin receptor activation reduces cyclin-dependent kinase 5 (Cdk5) expression [178], and this increase in Cdk5 expression attenuates fear memory retrieval [179]; therefore, the relationship between the dopamine D2 receptors and PTSD-like behaviors in Fabp3 null mice can be explored. Further 
studies are necessary to establish the mechanisms underlying the impaired fear extinction in Fabp3 null mice. On the other hand, melatonin receptor agonist, ramelteon, antagonized the PTSD-like behaviors in Fabp3 null mice, and therefore, we suggest that melatonin receptors may be a novel therapeutic target and ramelteon can be an effective drug candidate for the PTSD symptoms. As ramelteon has been approved for insomnia, preclinical studies and clinical trials will be helpful in the establishment of ramelteon as a PTSD therapy in the near future.

Funding: This work was supported in part by grants-in-aid for Scientific Research from the Ministry of Education, Science, Sports and Culture of Japan (Kakenhi: 26102704 to K.F.), Takeda Science Foundation (to Y.Y.), and the Strategic Research Program for Brain Sciences from Japan Agency for Medical Research and Development, AMED (to K.F.).

Conflicts of Interest: The authors declare no conflict of interest.

\section{Abbreviations}

$\begin{array}{ll}\text { ACC } & \text { anterior cingulated cortex } \\ \text { BLA } & \text { basolateral amygdala } \\ \text { CaMKII } & \text { calcium/calmodulin-dependent protein kinase II } \\ \text { CBT } & \text { cognitive behavioral therapy } \\ \text { Cdk5 } & \text { cyclin-dependent kinase 5 } \\ \text { DG } & \text { dentate gyrus } \\ \text { EMDR } & \text { eye movement desensitization and reprocessing } \\ \text { FABP } & \text { fatty acid binding protein } \\ \text { fMRI } & \text { functional magnetic resonance imaging } \\ \text { GABA } & \gamma \text {-aminobutyric acid } \\ \text { HPA } & \text { hypothalamo-pituitary-adrenal } \\ \text { 5-HT } & \text { serotonin } \\ \text { IRT } & \text { imagery rehearsal therapy } \\ \text { LCPUFA } & \text { long-chain polyunsaturated fatty acid } \\ \text { MRI } & \text { magnetic resonance imaging } \\ \text { NMDA } & N \text {-methyl- } d \text {-aspartate } \\ \text { PFC } & \text { prefrontal cortex } \\ \text { PTSD } & \text { Post-traumatic stress disorder } \\ \text { QOL } & \text { quality of life } \\ \text { SNRI } & \text { serotonin and noradrenaline reuptake inhibitor } \\ \text { SPS } & \text { Single prolonged stress } \\ \text { SSRI } & \text { selective serotonin reuptake inhibitor } \\ \text { WT } & \text { wild-type } \\ & \end{array}$

\section{References}

1. Foa, E.B.; Gillihan, S.J.; Bryant, R.A. Challenges and Successes in Dissemination of Evidence-Based Treatments for Posttraumatic Stress: Lessons Learned From Prolonged Exposure Therapy for PTSD. Psychol. Sci. Public Interest 2013, 14, 65-111. [CrossRef] [PubMed]

2. Javidi, H.; Yadollahie, M. Post-traumatic Stress Disorder. Int. J. Occup. Environ Med. 2012, 3, 2-9. [PubMed]

3. Kessler, R.C.; Chiu, W.T.; Demler, O.; Merikangas, K.R.; Walters, E.E. Prevalence, severity, and comorbidity of 12-month DSM-IV disorders in the National Comorbidity Survey Replication. Arch. Gen. Psychiatry 2005, 62, 617-627. [CrossRef] [PubMed]

4. Goldstein, R.B.; Smith, S.M.; Chou, S.P.; Saha, T.D.; Jung, J.; Zhang, H.; Pickering, R.P.; Ruan, W.J.; Huang, B.; Grant, B.F. The epidemiology of DSM-5 posttraumatic stress disorder in the United States: Results from the National Epidemiologic Survey on Alcohol and Related Conditions-III. Soc. Psychiatry Psychiatr. Epidemiol. 2016, 51, 1137-1148. [CrossRef]

5. Kawakami, N.; Tsuchiya, M.; Umeda, M.; Koenen, K.C.; Kessler, R.C. World Mental Health Survey Japan. Trauma and posttraumatic stress disorder in Japan: Results from the World Mental Health Japan Survey. J. Psychiatr. Res. 2014, 53, 157-165. [CrossRef] 
6. Fullerton, C.S.; Ursano, R.J.; Wang, L. Acute stress disorder, posttraumatic stress disorder, and depression in disaster or rescue workers. Am. J. Psychiatry 2004, 161, 1370-1376. [CrossRef]

7. Matsubara, C.; Murakami, H.; Imai, K.; Mizoue, T.; Akashi, H.; Miyoshi, C.; Nakasa, T. Prevalence and Risk Factors for Post-Traumatic Stress Reaction Among Resident Survivors of the Tsunami That Followed the Great East Japan Earthquake, March 11, 2011. Disaster Med. Public Health Prep. 2016, 10, 746-753. [CrossRef]

8. Schlenger, W.E.; Caddell, J.M.; Ebert, L.; Jordan, B.K.; Rourke, K.M.; Wilson, D.; Thalji, L.; Dennis, J.M.; Fairbank, J.A.; Kulka, R.A. Psychological reactions to terrorist attacks: Findings from the National Study of Americans' Reactions to September 11. JAMA 2002, 288, 581-588. [CrossRef]

9. Turner, S.W.; Thompson, J.; Rosser, R.M. The Kings Cross fire: Psychological reactions. J. Trauma Stress 1995, 8, 419-427. [CrossRef]

10. Havenaar, J.M.; Rumyantzeva, G.M.; van den Brink, W.; Poelijoe, N.W.; van den Bout, J.; van Engeland, H.; Koeter, M.W. Long-term mental health effects of the Chernobyl disaster: An epidemiologic survey in two former Soviet regions. Am. J. Psychiatry 1997, 154, 1605-1607. [CrossRef]

11. Ressler, K.J.; Mayberg, H.S. Targeting abnormal neural circuits in mood and anxiety disorders: From the laboratory to the clinic. Nat. Neurosci. 2007, 10, 1116-1124. [CrossRef] [PubMed]

12. Waltman, S.H.; Shearer, D.; Moore, B.A. Management of Post-Traumatic Nightmares: A Review of Pharmacologic and Nonpharmacologic Treatments Since 2013. Curr. Psychiatry Rep. 2018, 20, 108. [CrossRef] [PubMed]

13. Bremner, J.D.; Scott, T.M.; Delaney, R.C.; Southwick, S.M.; Mason, J.W.; Johnson, D.R.; Innis, R.B.; McCarthy, G.; Charney, D.S. Deficits in short-term memory in posttraumatic stress disorder. Am. J. Psychiatry 1993, 150, 1015-1019. [CrossRef] [PubMed]

14. Vasterling, J.J.; Duke, L.M.; Brailey, K.; Constans, J.I.; Allain, A.N., Jr.; Sutker, P.B. Attention, learning, and memory performances and intellectual resources in Vietnam veterans: PTSD and no disorder comparisons. Neuropsychology 2002, 16, 5-14. [CrossRef] [PubMed]

15. Moser, D.A.; Aue, T.; Suardi, F.; Kutlikova, H.; Cordero, M.I.; Rossignol, A.S.; Favez, N.; Rusconi Serpa, S.; Schechter, D.S. Violence-related PTSD and neural activation when seeing emotionally charged male-female interactions. Soc. Cogn. Affect. Neurosci. 2015, 10, 645-653. [CrossRef]

16. Yu, B.; Cui, S.Y.; Zhang, X.Q.; Cui, X.Y.; Li, S.J.; Sheng, Z.F.; Cao, Q.; Huang, Y.L.; Xu, Y.P.; Lin, Z.G.; et al. Different neural circuitry is involved in physiological and psychological stress-induced PTSD-like "nightmares" in rats. Sci. Rep. 2015, 5, 15976. [CrossRef]

17. Paintain, E.; Cassidy, S. First-line therapy for post-traumatic stress disorder: A systematic review of cognitive behavioural therapy and psychodynamic approaches. Couns. Psychother. Res. 2018, 18, 237-250. [CrossRef]

18. Forman-Hoffman, V.; Middleton, J.C.; Feltner, C.; Gaynes, B.N.; Weber, R.P.; Bann, C.; Viswanathan, M.; Lohr, K.N.; Baker, C.; Green, J. Psychological and Pharmacological Treatments for Adults With Posttraumatic Stress Disorder: A Systematic Review Update; Report No.: 18-EHC011-EF; Agency for Healthcare Research and Quality (US): Rockville, MD, USA, 2018.

19. Milad, M.R.; Quirk, G.J. Neurons in medial prefrontal cortex signal memory for fear extinction. Nature 2002, 420, 70-74. [CrossRef]

20. Parsons, R.G.; Ressler, K.J. Implications of memory modulation for post-traumatic stress and fear disorders. Nat. Neurosci. 2013, 16, 146-153. [CrossRef]

21. Wilensky, A.E.; Schafe, G.E.; Kristensen, M.P.; LeDoux, J.E. Rethinking the fear circuit: The central nucleus of the amygdala is required for the acquisition, consolidation, and expression of Pavlovian fear conditioning. J. Neurosci. 2006, 26, 12387-12396. [CrossRef]

22. Quirk, G.J.; Russo, G.K.; Barron, J.L.; Lebron, K. The role of ventromedial prefrontal cortex in the recovery of extinguished fear. J. Neurosci. 2000, 20, 6225-6231. [CrossRef] [PubMed]

23. Kim, J.J.; Fanselow, M.S. Modality-specific retrograde amnesia of fear. Science 1992, 256, 675-677. [CrossRef] [PubMed]

24. Sanders, M.J.; Fanselow, M.S. Pre-training prevents context fear conditioning deficits produced by hippocampal NMDA receptor blockade. Neurobiol. Learn Mem. 2003, 80, 123-129. [CrossRef]

25. Sotres-Bayon, F.; Sierra-Mercado, D.; Pardilla-Delgado, E.; Quirk, G.J. Gating of Fear in Prelimbic Cortex by Hippocampal and Amygdala Inputs. Neuron 2012, 76, 804-812. [CrossRef] [PubMed]

26. Tovote, P.; Fadok, J.P.; Lüthi, A. Neuronal circuits for fear and anxiety. Nat. Rev. Neurosci. 2015, 16, 317-331. [CrossRef] [PubMed] 
27. Klavir, O.; Prigge, M.; Sarel, A.; Paz, R.; Yizhar, O. Manipulating fear associations via optogenetic modulation of amygdala inputs to prefrontal cortex. Nat. Neurosci. 2017, 20, 836-844. [CrossRef]

28. Kitayama, N.; Vaccarino, V.; Kutner, M.; Weiss, P.; Bremner, J.D. Magnetic resonance imaging (MRI) measurement of hippocampal volume in posttraumatic stress disorder: A meta-analysis. J. Affect. Disord. 2005, 88, 79-86. [CrossRef] [PubMed]

29. Yamasue, H.; Kasai, K.; Iwanami, A.; Ohtani, T.; Yamada, H.; Abe, O.; Kuroki, N.; Fukuda, R.; Sadamatsu, M.; Sasaki, T.; et al. Voxel-based analysis of MRI reveals anterior cingulate gray-matter volume reduction in posttraumatic stress disorder due to terrorism. Proc. Natl. Acad. Sci. USA 2003, 100, 9039-9043. [CrossRef]

30. O'Doherty, D.C.; Chitty, K.M.; Saddiqui, S.; Bennett, M.R.; Lagopoulos, J. A systematic review and meta-analysis of magnetic resonance imaging measurement of structural volumes in posttraumatic stress disorder. Psychiatry Res. 2015, 232, 1-33. [CrossRef]

31. Rauch, S.L.; Shin, L.M.; Phelps, E.A. Neurocircuitry models of posttraumatic stress disorder and extinction: Human neuroimaging research-past, present, and future. Biol. Psychiatry 2006, 60, 376-382. [CrossRef] [PubMed]

32. Logue, M.W.; van Rooij, S.J.H.; Dennis, E.L.; Davis, S.L.; Hayes, J.P.; Stevens, J.S.; Densmore, M.; Haswell, C.C.; Ipser, J.; Koch, S.B.J.; et al. Smaller Hippocampal Volume in Posttraumatic Stress Disorder: A Multisite ENIGMA-PGC Study: Subcortical Volumetry Results From Posttraumatic Stress Disorder Consortia. Biol. Psychiatry 2018, 83, 244-253. [CrossRef] [PubMed]

33. Shin, L.M.; Wright, C.I.; Cannistraro, P.A.; Wedig, M.M.; McMullin, K.; Martis, B.; Macklin, M.L.; Lasko, N.B.; Cavanagh, S.R.; Krangel, T.S.; et al. A functional magnetic resonance imaging study of amygdala and medial prefrontal cortex responses to overtly presented fearful faces in posttraumatic stress disorder. Arch Gen. Psychiatry 2005, 62, 273-281. [CrossRef] [PubMed]

34. Rauch, S.L.; Whalen, P.J.; Shin, L.M.; McInerney, S.C.; Macklin, M.L.; Lasko, N.B.; Orr, S.P.; Pitman, R.K. Exaggerated amygdala response to masked facial stimuli in posttraumatic stress disorder: A functional MRI study. Biol. Psychiatry 2000, 47, 769-776. [CrossRef]

35. Shin, L.M.; Whalen, P.J.; Pitman, R.K.; Bush, G.; Macklin, M.L.; Lasko, N.B.; Orr, S.P.; McInerney, S.C.; Rauch, S.L. An fMRI study of anterior cingulate function in posttraumatic stress disorder. Biol. Psychiatry 2001, 50, 932-942. [CrossRef]

36. Patel, R.; Spreng, R.N.; Shin, L.M.; Girard, T.A. Neurocircuitry models of posttraumatic stress disorder and beyond: A meta-analysis of functional neuroimaging studies. Neurosci. Biobehav. Rev. 2012, 36, 2130-2142. [CrossRef] [PubMed]

37. Lanius, R.A.; Frewen, P.A.; Tursich, M.; Jetly, R.; McKinnon, M.C. Restoring large-scale brain networks in PTSD and related disorders: A proposal for neuroscientifically-informed treatment interventions. Eur. J. Psychotraumatol. 2015, 6, 27313. [CrossRef] [PubMed]

38. Hayes, J.P.; Hayes, S.M.; Mikedis, A.M. Quantitative meta-analysis of neural activity in posttraumatic stress disorder. Biol. Mood Anxiety Disord. 2012, 2, 9. [CrossRef] [PubMed]

39. Koch, S.B.; van Zuiden, M.; Nawijn, L.; Frijling, J.L.; Veltman, D.J.; Olff, M. Aberrant resting-state brain activity in posttraumatic stress disorder: A meta-analysis and systematic review. Depress. Anxiety 2016, 33, 592-605. [CrossRef]

40. Bremner, J.D.; Staib, L.H.; Kaloupek, D.; Southwick, S.M.; Soufer, R.; Charney, D.S. Neural correlates of exposure to traumatic pictures and sound in Vietnam combat veterans with and without posttraumatic stress disorder: A positron emission tomography study. Biol. Psychiatry 1999, 45, 806-816. [CrossRef]

41. Feng, P.; Feng, T.; Chen, Z.; Lei, X. Memory consolidation of fear conditioning: Bi-stable amygdala connectivity with dorsal anterior cingulate and medial prefrontal cortex. Soc. Cogn. Affect. Neurosci. 2014, 9, 1730-1737. [CrossRef]

42. Jeon, D.; Kim, S.; Chetana, M.; Jo, D.; Ruley, H.E.; Lin, S.Y.; Rabah, D.; Kinet, J.P.; Shin, H.S. Observational fear learning involves affective pain system and Cav1.2 Ca2+ channels in ACC. Nat. Neurosci. 2010, 13, 482-488. [CrossRef] [PubMed]

43. Mátyás, F.; Lee, J.; Shin, H.S.; Acsády, L. The fear circuit of the mouse forebrain: Connections between the mediodorsal thalamus, frontal cortices and basolateral amygdala. Eur. J. Neurosci. 2014, 39, 1810-1823. [CrossRef] [PubMed]

44. Duman, R.S.; Girgenti, M.J. Molecular and cellular studies of PTSD: Postmortem transcriptome analysis and novel therapeutic targets. J. Neurosci. Res. 2019, 97, 292-299. [CrossRef] [PubMed] 
45. Myers, K.M.; Davis, M. Mechanisms of fear extinction. Mol. Psychiatry 2007, 12, 120-150. [CrossRef] [PubMed]

46. Roy, M.J.; Francis, J.; Friedlander, J.; Banks-Williams, L.; Lande, R.G.; Taylor, P.; Blair, J.; McLellan, J.; Law, W.; Tarpley, V.; et al. Improvement in cerebral function with treatment of posttraumatic stress disorder. Ann. N. Y. Acad. Sci. 2010, 1208, 142-149. [CrossRef] [PubMed]

47. Szeszko, P.R.; Yehuda, R. Magnetic resonance imaging predictors of psychotherapy treatment response in post-traumatic stress disorder: A role for the salience network. Psychiatry Res. 2019, 277, 52-57. [CrossRef] [PubMed]

48. Flanagan, J.C.; Hand, A.; Jarnecke, A.M.; Moran-Santa Maria, M.M.; Brady, K.T.; Joseph, J.E. Effects of oxytocin on working memory and executive control system connectivity in posttraumatic stress disorder. Exp. Clin. Psychopharmacol. 2018, 26, 391-402. [CrossRef]

49. Bossini, L.; Tavanti, M.; Lombardelli, A.; Calossi, S.; Polizzotto, N.R.; Galli, R.; Vatti, G.; Pieraccini, F.; Castrogiovanni, P. Changes in hippocampal volume in patients with post-traumatic stress disorder after sertraline treatment. J. Clin. Psychopharmacol. 2007, 27, 233-235. [CrossRef]

50. Vermetten, E.; Vythilingam, M.; Southwick, S.M.; Charney, D.S.; Bremner, J.D. Long-term treatment with paroxetine increases verbal declarative memory and hippocampal volume in posttraumatic stress disorder. Biol. Psychiatry 2003, 54, 693-702. [CrossRef]

51. Letizia, B.; Andrea, F.; Paolo, C. Neuroanatomical changes after eye movement desensitization and reprocessing (EMDR) treatment in posttraumatic stress disorder. J. Neuropsychiatry Clin. Neurosci. 2007, 19, 475-476. [CrossRef]

52. Nardo, D.; Högberg, G.; Looi, J.C.; Larsson, S.; Hällström, T.; Pagani, M. Gray matter density in limbic and paralimbic cortices is associated with trauma load and EMDR outcome in PTSD patients. J. Psychiatry Res. 2010, 44, 477-485. [CrossRef] [PubMed]

53. Bryant, R.A.; Felmingham, K.; Whitford, T.J.; Kemp, A.; Hughes, G.; Peduto, A.; Williams, L.M. Rostral anterior cingulate volume predicts treatment response to cognitive-behavioural therapy for posttraumatic stress disorder. J. Psychiatry Neurosci. 2008, 33, 142-146. [CrossRef] [PubMed]

54. National Institute for Clinical Excellence (NICE). Post-Traumatic Stress Disorder: Management (CG26); National Institute for Health and Clinical Excellence: Manchester, UK, 2005.

55. Kar, N. Cognitive behavioral therapy for the treatment of post-traumatic stress disorder: A review. Neuropsychiatry Dis. Treat. 2011, 7, 167-181. [CrossRef] [PubMed]

56. Lee, D.J.; Schnitzlein, C.W.; Wolf, J.P.; Vythilingam, M.; Rasmusson, A.M.; Hoge, C.W. Psychotherapy versus pharmacotherapy for posttraumatic stress disorder: Systemic review and meta-analyses to determine first-line treatments. Depress. Anxiety 2016, 33, 792-806. [CrossRef] [PubMed]

57. Resick, P.A.; Nishith, P.; Weaver, T.L.; Astin, M.C.; Feuer, C.A. A comparison of cognitive-processing therapy with prolonged exposure and a waiting condition for the treatment of chronic posttraumatic stress disorder in female rape victims. J. Consult. Clin. Psychol. 2002, 70, 867-879. [CrossRef] [PubMed]

58. Asukai, N.; Saito, A.; Tsuruta, N.; Kishimoto, J.; Nishikawa, T. Efficacy of exposure therapy for Japanese patients with posttraumatic stress disorder due to mixed traumatic events: A randomized controlled study. J. Trauma Stress 2010, 23, 744-750. [CrossRef]

59. Monson, C.M.; Fredman, S.J.; Macdonald, A.; Pukay-Martin, N.D.; Resick, P.A.; Schnurr, P.P. Effect of cognitive-behavioral couple therapy for PTSD: A randomized controlled trial. JAMA 2012, 308, 700-709. [CrossRef] [PubMed]

60. Hollifield, M.; Sinclair-Lian, N.; Warner, T.D.; Hammerschlag, R. Acupuncture for posttraumatic stress disorder: A randomized controlled pilot trial. J. Nerv. Ment. Dis. 2007, 195, 504-513. [CrossRef]

61. Ehlers, A.; Hackmann, A.; Grey, N.; Wild, J.; Liness, S.; Albert, I.; Deale, A.; Stott, R.; Clark, D.M. A randomized controlled trial of 7-day intensive and standard weekly cognitive therapy for PTSD and emotion-focused supportive therapy. Am. J. Psychiatry 2014, 171, 294-304. [CrossRef]

62. Ter Heide, F.J.; Mooren, T.M.; van de Schoot, R.; de Jongh, A.; Kleber, R.J. Eye movement desensitisation and reprocessing therapy v. stabilisation as usual for refugees: Randomised controlled trial. Br. J. Psychiatry 2016, 209, 311-318. [CrossRef]

63. Carlson, J.G.; Chemtob, C.M.; Rusnak, K.; Hedlund, N.L.; Muraoka, M.Y. Eye movement desensitization and reprocessing (EDMR) treatment for combat-related posttraumatic stress disorder. J. Trauma Stress 1998, 11, 3-24. [CrossRef] [PubMed] 
64. van der Kolk, B.A.; Spinazzola, J.; Blaustein, M.E.; Hopper, J.W.; Hopper, E.K.; Korn, D.L.; Simpson, W.B. A randomized clinical trial of eye movement desensitization and reprocessing (EMDR), fluoxetine, and pill placebo in the treatment of posttraumatic stress disorder: Treatment effects and long-term maintenance. J. Clin. Psychiatry 2007, 68, 37-46. [CrossRef] [PubMed]

65. Krakow, B.; Hollifield, M.; Johnston, L.; Koss, M.; Schrader, R.; Warner, T.D.; Tandberg, D.; Lauriello, J.; McBride, L.; Cutchen, L.; et al. Imagery rehearsal therapy for chronic nightmares in sexual assault survivors with posttraumatic stress disorder: A randomized controlled trial. JAMA 2001, 286, 537-545. [CrossRef]

66. Boden, M.T.; Kimerling, R.; Jacobs-Lentz, J.; Bowman, D.; Weaver, C.; Carney, D.; Walser, R.; Trafton, J.A. Seeking Safety treatment for male veterans with a substance use disorder and post-traumatic stress disorder symptomatology. Addiction 2012, 107, 578-586. [CrossRef] [PubMed]

67. Galovski, T.E.; Blain, L.M.; Mott, J.M.; Elwood, L.; Houle, T. Manualized therapy for PTSD: Flexing the structure of cognitive processing therapy. J. Consult. Clin. Psychol. 2012, 80, 968-981. [CrossRef] [PubMed]

68. Martenyi, F.; Brown, E.B.; Zhang, H.; Prakash, A.; Koke, S.C. Fluoxetine versus placebo in posttraumatic stress disorder. J. Clin. Psychiatry 2002, 63, 199-206. [CrossRef]

69. van der Kolk, B.A.; Dreyfuss, D.; Michaels, M.; Shera, D.; Berkowitz, R.; Fisler, R.; Saxe, G. Fluoxetine in posttraumatic stress disorder. J. Clin. Psychiatry 1994, 55, 517-522. [PubMed]

70. Martenyi, F.; Brown, E.B.; Caldwell, C.D. Failed efficacy of fluoxetine in the treatment of posttraumatic stress disorder: Results of a fixed-dose, placebo-controlled study. J. Clin. Psychopharmacol. 2007, 27, 166-170. [CrossRef]

71. Marshall, R.D.; Beebe, K.L.; Oldham, M.; Zaninelli, R. Efficacy and safety of paroxetine treatment for chronic PTSD: A fixed-dose, placebo-controlled study. Am. J. Psychiatry 2001, 158, 1982-1988. [CrossRef]

72. Tucker, P.; Zaninelli, R.; Yehuda, R.; Ruggiero, L.; Dillingham, K.; Pitts, C.D. Paroxetine in the treatment of chronic posttraumatic stress disorder: Results of a placebo-controlled, flexible-dosage trial. J. Clin. Psychiatry 2001, 62, 860-868. [CrossRef]

73. Brady, K.; Pearlstein, T.; Asnis, G.M.; Baker, D.; Rothbaum, B.; Sikes, C.R.; Farfel, G.M. Efficacy and safety of sertraline treatment of posttraumatic stress disorder: A randomized controlled trial. JAMA 2000, 283, 1837-1844. [CrossRef] [PubMed]

74. Davidson, J.R.; Rothbaum, B.O.; van der Kolk, B.A.; Sikes, C.R.; Farfel, G.M. Multicenter, double-blind comparison of sertraline and placebo in the treatment of posttraumatic stress disorder. Arch. Gen. Psychiatry 2001, 58, 485-492. [CrossRef] [PubMed]

75. Zohar, J.; Amital, D.; Miodownik, C.; Kotler, M.; Bleich, A.; Lane, R.M.; Austin, C. Double-blind placebo-controlled pilot study of sertraline in military veterans with posttraumatic stress disorder. J. Clin. Psychopharmacol. 2002, 22, 190-195. [CrossRef] [PubMed]

76. Davidson, J.; Rothbaum, B.O.; Tucker, P.; Asnis, G.; Benattia, I.; Musgnung, J.J. Venlafaxine extended release in posttraumatic stress disorder: A sertraline- and placebo-controlled study. J. Clin. Psychopharmacol. 2006, 26, 259-267. [CrossRef] [PubMed]

77. Davidson, J.; Baldwin, D.; Stein, D.J.; Kuper, E.; Benattia, I.; Ahmed, S.; Pedersen, R.; Musgnung, J. Treatment of posttraumatic stress disorder with venlafaxine extended release: A 6-month randomized controlled trial. Arch. Gen. Psychiatry 2006, 63, 1158-1165. [CrossRef] [PubMed]

78. Kosten, T.R.; Frank, J.B.; Dan, E.; McDougle, C.J.; Giller, E.L., Jr. Pharmacotherapy for posttraumatic stress disorder using phenelzine or imipramine. J. Nerv. Ment. Dis. 1991, 179, 366-370. [CrossRef]

79. Davidson, J.; Kudler, H.; Smith, R.; Mahorney, S.L.; Lipper, S.; Hammett, E.; Saunders, W.B.; Cavenar, J.O., Jr. Treatment of posttraumatic stress disorder with amitriptyline and placebo. Arch. Gen. Psychiatry 1990, 47, 259-266. [CrossRef] [PubMed]

80. Davidson, J.R.; Weisler, R.H.; Butterfield, M.I.; Casat, C.D.; Connor, K.M.; Barnett, S.; van Meter, S. Mirtazapine vs. placebo in posttraumatic stress disorder: A pilot trial. Biol. Psychiatry 2003, 53, 188-191. [CrossRef]

81. Becker, M.E.; Hertzberg, M.A.; Moore, S.D.; Dennis, M.F.; Bukenya, D.S.; Beckham, J.C. A placebo-controlled trial of bupropion SR in the treatment of chronic posttraumatic stress disorder. J. Clin. Psychopharmacol. 2007, 27, 193-197. [CrossRef]

82. Hamner, M.B.; Faldowski, R.A.; Ulmer, H.G.; Frueh, B.C.; Huber, M.G.; Arana, G.W. Adjunctive risperidone treatment in post-traumatic stress disorder: A preliminary controlled trial of effects on comorbid psychotic symptoms. Int. Clin. Psychopharmacol. 2003, 18, 1-8. [CrossRef] 
83. Reich, D.B.; Winternitz, S.; Hennen, J.; Watts, T.; Stanculescu, C. A preliminary study of risperidone in the treatment of posttraumatic stress disorder related to childhood abuse in women. J. Clin. Psychiatry 2004, 65, 1601-1606. [CrossRef] [PubMed]

84. Krystal, J.H.; Rosenheck, R.A.; Cramer, J.A.; Vessicchio, J.C.; Jones, K.M.; Vertrees, J.E.; Horney, R.A.; Huang, G.D.; Stock, C. Veterans, Affairs, Cooperative, Study, No. 504 Group. Adjunctive risperidone treatment for antidepressant-resistant symptoms of chronic military service-related PTSD: A randomized trial. JAMA 2011, 306, 493-502. [CrossRef] [PubMed]

85. Stein, M.B.; Kline, N.A.; Matloff, J.L. Adjunctive olanzapine for SSRI-resistant combat-related PTSD: A double-blind, placebo-controlled study. Am. J. Psychiatry 2002, 159, 1777-1779. [CrossRef] [PubMed]

86. Carey, P.; Suliman, S.; Ganesan, K.; Seedat, S.; Stein, D.J. Olanzapine monotherapy in posttraumatic stress disorder: Efficacy in a randomized, double-blind, placebo-controlled study. Hum. Psychopharmacol. 2012, 27, 386-391. [CrossRef] [PubMed]

87. Lambert, M.T. Aripiprazole in the management of post-traumatic stress disorder symptoms in returning Global War on Terrorism veterans. Int. Clin. Psychopharmacol. 2006, 21, 185-187. [CrossRef]

88. Hamner, M.B.; Brodrick, P.S.; Labbate, L.A. Gabapentin in PTSD: A retrospective, clinical series of adjunctive therapy. Ann. Clin. Psychiatry 2001, 13, 141-146. [CrossRef]

89. Raskind, M.A.; Peskind, E.R.; Kanter, E.D.; Petrie, E.C.; Radant, A.; Thompson, C.E.; Dobie, D.J.; Hoff, D.; Rein, R.J.; Straits-Tröster, K.; et al. Reduction of nightmares and other PTSD symptoms in combat veterans by prazosin: A placebo-controlled study. Am. J. Psychiatry 2003, 160, 371-373. [CrossRef]

90. Raskind, M.A.; Peterson, K.; Williams, T.; Hoff, D.J.; Hart, K.; Holmes, H.; Homas, D.; Hill, J.; Daniels, C.; Calohan, J.; et al. A trial of prazosin for combat trauma PTSD with nightmares in active-duty soldiers returned from Iraq and Afghanistan. Am. J. Psychiatry 2013, 170, 1003-1010. [CrossRef]

91. Raskind, M.A.; Peskind, E.R.; Chow, B.; Harris, C.; Davis-Karim, A.; Holmes, H.A.; Hart, K.L.; McFall, M.; Mellman, T.A.; Reist, C.; et al. Trial of Prazosin for Post-Traumatic Stress Disorder in Military Veterans. N. Engl. J. Med. 2018, 378, 507-517. [CrossRef]

92. Tucker, P.; Trautman, R.P.; Wyatt, D.B.; Thompson, J.; Wu, S.C.; Capece, J.A.; Rosenthal, N.R. Efficacy and safety of topiramate monotherapy in civilian posttraumatic stress disorder: A randomized, double-blind, placebo-controlled study. J. Clin. Psychiatry 2007, 68, 201-206. [CrossRef]

93. Yeh, M.S.; Mari, J.J.; Costa, M.C.; Andreoli, S.B.; Bressan, R.A.; Mello, M.F. A double-blind randomized controlled trial to study the efficacy of topiramate in a civilian sample of PTSD. CNS Neurosci. Ther. 2011, 17, 305-310. [CrossRef] [PubMed]

94. Jetly, R.; Heber, A.; Fraser, G.; Boisvert, D. The efficacy of nabilone, a synthetic cannabinoid, in the treatment of PTSD-associated nightmares: A preliminary randomized, double-blind, placebo-controlled cross-over design study. Psychoneuroendocrinology 2015, 51, 585-588. [CrossRef] [PubMed]

95. Gunduz-Cinar, O.; Flynn, S.; Brockway, E.; Kaugars, K.; Baldi, R.; Ramikie, T.S.; Cinar, R.; Kunos, G.; Patel, S.; Holmes, A. Fluoxetine Facilitates Fear Extinction Through Amygdala Endocannabinoids. Neuropsychopharmacology 2016, 41, 1598-1609. [CrossRef] [PubMed]

96. Deschaux, O.; Spennato, G.; Moreau, J.L.; Garcia, R. Chronic treatment with fluoxetine prevents the return of extinguished auditory-cued conditioned fear. Psychopharmacology 2011, 215, 231-237. [CrossRef] [PubMed]

97. Bentefour, Y.; Rakibi, Y.; Bennis, M.; Ba-M’hamed, S.; Garcia, R. Paroxetine treatment, following behavioral suppression of PTSD-like symptoms in mice, prevents relapse by activating the infralimbic cortex. Eur. Neuropsychopharmacol. 2016, 26, 195-207. [CrossRef]

98. Alvarez-Ricartes, N.; Oliveros-Matus, P.; Mendoza, C.; Perez-Urrutia, N.; Echeverria, F.; Iarkov, A.; Barreto, G.E.; Echeverria, V. Intranasal Cotinine Plus Krill Oil Facilitates Fear Extinction, Decreases Depressive-Like Behavior, and Increases Hippocampal Calcineurin A Levels in Mice. Mol. Neurobiol. 2018, 55, 7949-7960. [CrossRef] [PubMed]

99. Yang, C.H.; Shi, H.S.; Zhu, W.L.; Wu, P.; Sun, L.L.; Si, J.J.; Liu, M.M.; Zhang, Y.; Suo, L.; Yang, J.L. Venlafaxine facilitates between-session extinction and prevents reinstatement of auditory-cue conditioned fear. Behav. Brain Res. 2012, 230, 268-273. [CrossRef]

100. Kakui, N.; Yokoyama, F.; Yamauchi, M.; Kitamura, K.; Imanishi, T.; Inoue, T.; Koyama, T. Anxiolytic-like profile of mirtazapine in rat conditioned fear stress model: Functional significance of 5-hydroxytryptamine 1A receptor and alpha1-adrenergic receptor. Pharmacol. Biochem. Behav. 2009, 92, 393-398. [CrossRef] 
101. An, Y.; Inoue, T.; Kitaichi, Y.; Nakagawa, S.; Wang, C.; Chen, C.; Song, N.; Kusumi, I. Combined treatment with subchronic lithium and acute intracerebral mirtazapine microinjection into the median raphe nucleus exerted an anxiolytic-like effect synergistically. Eur. J. Pharmacol. 2016, 783, 112-116. [CrossRef]

102. Sun, T.; He, W.; Hu, G.; Li, M. Anxiolytic-like property of risperidone and olanzapine as examined in multiple measures of fear in rats. Pharmacol. Biochem. Behav. 2010, 95, 298-307. [CrossRef]

103. Milstein, J.A.; Elnabawi, A.; Vinish, M.; Swanson, T.; Enos, J.K.; Bailey, A.M.; Kolb, B.; Frost, D.O. Olanzapine treatment of adolescent rats causes enduring specific memory impairments and alters cortical development and function. PLoS ONE 2013, 8, e57308. [CrossRef] [PubMed]

104. Ganella, D.E.; Lee-Kardashyan, L.; Luikinga, S.J.; Nguyen, D.L.D.; Madsen, H.B.; Zbukvic, I.C.; Coulthard, R.; Lawrence, A.J.; Kim, J.H. Aripiprazole Facilitates Extinction of Conditioned Fear in Adolescent Rats. Front. Behav. Neurosci. 2017, 11, 76. [CrossRef] [PubMed]

105. Dubrovina, N.I.; Zinov'eva, D.V. Effects of activation and blockade of dopamine receptors on the extinction of a passive avoidance reaction in mice with a depressive-like state. Neurosci. Behav. Physiol. 2010, 40, 55-59. [CrossRef] [PubMed]

106. Nicolas, L.B.; Klein, S.; Prinssen, E.P. Defensive-like behaviors induced by ultrasound: Further pharmacological characterization in Lister-hooded rats. Psychopharmacology 2007, 194, 243-252. [CrossRef] [PubMed]

107. Gazarini, L.; Stern, C.A.; Carobrez, A.P.; Bertoglio, L.J. Enhanced noradrenergic activity potentiates fear memory consolidation and reconsolidation by differentially recruiting $\alpha 1$ - and $\beta$-adrenergic receptors. Learn. Mem. 2013, 20, 210-219. [CrossRef]

108. Lucas, E.K.; Wu, W.C.; Roman-Ortiz, C.; Clem, R.L. Prazosin during fear conditioning facilitates subsequent extinction in male C57Bl/6N mice. Psychopharmacology 2018, 236, 273-279. [CrossRef] [PubMed]

109. Schmidt do Prado-Lima, P.A.; Perrenoud, M.F.; Kristensen, C.H.; Cammarota, M.; Izquierdo, I. Topiramate diminishes fear memory consolidation and extinguishes conditioned fear in rats. J. Psychiatry Neurosci. 2011, 36, 250-255. [CrossRef]

110. Rau, V.; DeCola, J.P.; Fanselow, M.S. Stress-induced enhancement of fear learning: An animal model of posttraumatic stress disorder. Neurosci. Biobehav. Rev. 2005, 29, 1207-1223. [CrossRef]

111. Liberzon, I.; Krstov, M.; Young, E.A. Stress-restress: Effects on ACTH and fast feedback. Psychoneuroendocrinology 1997, 22, 443-453. [CrossRef]

112. Vanderheyden, W.M.; George, S.A.; Urpa, L.; Kehoe, M.; Liberzon, I.; Poe, G.R. Sleep alterations following exposure to stress predict fear-associated memory impairments in a rodent model of PTSD. Exp. Brain Res. 2015, 233, 2335-2346. [CrossRef]

113. Han, F.; Jiang, J.; Ding, J.; Liu, H.; Xiao, B.; Shi, Y. Change of Rin1 and Stathmin in the animal model of traumatic stresses. Front. Behav. Neurosci. 2017, 11, 62. [CrossRef] [PubMed]

114. Iwamoto, Y.; Morinobu, S.; Takahashi, T.; Yamawaki, S. Single prolonged stress increases contextual freezing and the expression of glycine transporter 1 and vesicle-associated membrane protein 2 mRNA in the hippocampus of rats. Prog. Neuro-Psychopharmacol. Biol. Psychiatry 2007, 31, 642-651. [CrossRef] [PubMed]

115. Keller, S.M.; Schreiber, W.B.; Stanfield, B.R.; Knox, D. Inhibiting corticosterone synthesis during fear memory formation exacerbates cued fear extinction memory deficits within the single prolonged stress model. Behav. Brain Res. 2015, 287, 182-186. [CrossRef]

116. Zoladz, P.R.; Conrad, C.D.; Fleshner, M.; Diamond, D.M. Acute episodes of predator exposure in conjunction with chronic social instability as an animal model of post-traumatic stress disorder. Stress 2008, 11, 259-281. [CrossRef] [PubMed]

117. Zoladz, P.R.; Fleshner, M.; Diamond, D.M. Psychosocial animal model of PTSD produces a long-lasting traumatic memory, an increase in general anxiety and PTSD-like glucocorticoid abnormalities. Psychoneuroendocrinology 2012, 37, 1531-1545. [CrossRef] [PubMed]

118. Cohen, H.; Zohar, J. An animal model of posttraumatic stress disorder: The use of cut-off behavioral criteria. Ann. N. Y. Acad. Sci. 2004, 1032, 167-178. [CrossRef] [PubMed]

119. Daskalakis, N.P.; Yehuda, R.; Diamond, D.M. Animal models in translational studies of PTSD. Psychoneuroendocrinology 2013, 38, 1895-1911. [CrossRef]

120. Maren, S.; Holmes, A. Stress and Fear Extinction. Neuropsychopharmacology 2016, 41, 58-79. [CrossRef]

121. Parks, C.L.; Robinson, P.S.; Sibille, E.; Shenk, T.; Toth, M. Increased anxiety of mice lacking the serotonin1A receptor. Proc. Natl. Acad. Sci. USA 1998, 95, 10734-10739. [CrossRef] 
122. Holmes, A.; Yang, R.J.; Lesch, K.P.; Crawley, J.N.; Murphy, D.L. Mice lacking the serotonin transporter exhibit 5-HT(1A) receptor-mediated abnormalities in tests for anxiety-like behavior. Neuropsychopharmacology 2003, 28, 2077-2088. [CrossRef]

123. Klemenhagen, K.C.; Gordon, J.A.; David, D.J.; Hen, R.; Gross, C.T. Increased fear response to contextual cues in mice lacking the 5-HT1A receptor. Neuropsychopharmacology 2006, 31, 101-111. [CrossRef] [PubMed]

124. Wellman, C.L.; Izquierdo, A.; Garrett, J.E.; Martin, K.P.; Carroll, J.; Millstein, R.; Lesch, K.P.; Murphy, D.L.; Holmes, A. Impaired stress-coping and fear extinction and abnormal corticolimbic morphology in serotonin transporter knock-out mice. J. Neurosci. 2007, 27, 684-691. [CrossRef]

125. Adamec, R.; Burton, P.; Blundell, J.; Murphy, D.L.; Holmes, A. Vulnerability to mild predator stress in serotonin transporter knockout mice. Behav. Brain Res. 2006, 170, 126-140. [CrossRef] [PubMed]

126. Jacobsen, K.X.; Czesak, M.; Deria, M.; Le François, B.; Albert, P.R. Region-specific regulation of 5-HT1A receptor expression by Pet-1-dependent mechanisms in vivo. J. Neurochem. 2011, 116, 1066-1076. [CrossRef] [PubMed]

127. Hendricks, T.J.; Fyodorov, D.V.; Wegman, L.J.; Lelutiu, N.B.; Pehek, E.A.; Yamamoto, B.; Silver, J.; Weeber, E.J.; Sweatt, J.D.; Deneris, E.S. Pet-1 ETS gene plays a critical role in 5-HT neuron development and is required for normal anxiety-like and aggressive behavior. Neuron 2003, 37, 233-247. [CrossRef]

128. Wellman, C.L.; Camp, M.; Jones, V.M.; MacPherson, K.P.; Ihne, J.; Fitzgerald, P.; Maroun, M.; Drabant, E.; Bogdan, R.; Hariri, A.R.; et al. Convergent effects of mouse Pet-1 deletion and human PET-1 variation on amygdala fear and threat processing. Exp. Neurol. 2013, 250, 260-269. [CrossRef] [PubMed]

129. Yu, H.; Wang, Y.; Pattwell, S.; Jing, D.; Liu, T.; Zhang, Y.; Bath, K.G.; Lee, F.S.; Chen, Z.Y. Variant BDNF Val66Met polymorphism affects extinction of conditioned aversive memory. J. Neurosci. 2009, 29, 4056-4064. [CrossRef] [PubMed]

130. Somerville, L.H.; Voss, H.U.; Glover, G.; Ballon, D.J.; Liston, C.; Teslovich, T.; Van Kempen, T.; Lee, F.S.; Casey, B.J. A genetic variant BDNF polymorphism alters extinction learning in both mouse and human. Science 2010, 327, 863-866. [CrossRef]

131. Thoeringer, C.K.; Henes, K.; Eder, M.; Dahlhoff, M.; Wurst, W.; Holsboer, F.; Deussing, J.M.; Moosmang, S.; Wotjak, C.T. Consolidation of remote fear memories involves Corticotropin-Releasing Hormone (CRH) receptor type 1-mediated enhancement of AMPA receptor GluR1 signaling in the dentate gyrus. Neuropsychopharmacology 2012, 37, 787-796. [CrossRef]

132. Verma, D.; Tasan, R.O.; Herzog, H.; Sperk, G. NPY controls fear conditioning and fear extinction by combined action on $\mathrm{Y}_{1}$ and $\mathrm{Y}_{2}$ receptors. Br. J. Pharmacol. 2012, 166, 1461-1473. [CrossRef]

133. Joseph, A.; Tang, M.; Mamiya, T.; Chen, Q.; Yang, L.L.; Jiao, J.; Yu, N.; Tang, Y.P. Temporal association of elevated cholecystokininergic tone and adolescent trauma is critical for posttraumatic stress disorder-like behavior in adult mice. Proc. Natl. Acad. Sci. USA 2013, 110, 6589-6594. [CrossRef] [PubMed]

134. Gordon, N. Nutrition and cognitive function. Brain Dev. 1997, 19, 165-170. [CrossRef]

135. Sakayori, N.; Kikkawa, T.; Tokuda, H.; Kiryu, E.; Yoshizaki, K.; Kawashima, H.; Yamada, T.; Arai, H.; Kang, J.X.; Katagiri, H.; et al. Maternal dietary imbalance between omega-6 and omega-3 polyunsaturated fatty acids impairs neocortical development via epoxy metabolites. Stem Cells 2016, 34, 470-482. [CrossRef] [PubMed]

136. Arvindakshan, M.; Ghate, M.; Ranjekar, P.K.; Evans, D.R.; Mahadik, S.P. Supplementation with a combination of omega-3 fatty acids and antioxidants (vitamins E and C) improves the outcome of schizophrenia. Schizophr. Res. 2003, 62, 195-204. [CrossRef]

137. Vancassel, S.; Durand, G.; Barthélémy, C.; Lejeune, B.; Martineau, J.; Guilloteau, D.; Andrès, C.; Chalon, S. Plasma fatty acid levels in autistic children. Prostaglandins Leukot. Essent. Fatty Acids 2011, 65, 1-7. [CrossRef] [PubMed]

138. Maekawa, M.; Takashima, N.; Matsumata, M.; Ikegami, S.; Kontani, M.; Hara, Y.; Kawashima, H.; Owada, Y.; Kiso, Y.; Yoshikawa, T.; et al. Arachidonic acid drives postnatal neurogenesis and elicits a beneficial effect on prepulse inhibition, a biological trait of psychiatric illnesses. PLoS ONE 2009, 4, e5085. [CrossRef] [PubMed]

139. de Vries, G.J.; Mocking, R.; Lok, A.; Assies, J.; Schene, A.; Olff, M. Fatty acid concentrations in patients with posttraumatic stress disorder compared to healthy controls. J. Affect. Disord. 2016, 205, 351-359. [CrossRef] [PubMed] 
140. Matsuoka, Y.; Nishi, D.; Nakaya, N.; Sone, T.; Hamazaki, K.; Hamazaki, T.; Koido, Y. Attenuating posttraumatic distress with omega-3 polyunsaturated fatty acids among disaster medical assistance team members after the Great East Japan Earthquake: The APOP randomized controlled trial. BMC Psychiatry 2011, 11, 132. [CrossRef]

141. Matsuoka, Y. Clearance of fear memory from the hippocampus through neurogenesis by omega-3 fatty acids: A novel preventive strategy for posttraumatic stress disorder? Biopsychosoc. Med. 2011, 5, 3. [CrossRef]

142. Matsuoka, Y.; Nishi, D.; Yonemoto, N.; Hamazaki, K.; Hashimoto, K.; Hamazaki, T. Omega-3 fatty acids for secondary prevention of posttraumatic stress disorder after accidental injury: An open-label pilot study. J. Clin. Psychopharmacol. 2010, 30, 217-219. [CrossRef]

143. Kitamura, T.; Saitoh, Y.; Takashima, N.; Murayama, A.; Niibori, Y.; Ageta, H.; Sekiguchi, M.; Sugiyama, H.; Inokuchi, K. Adult neurogenesis modulates the hippocampus-dependent period of associative fear memory. Cell 2009, 139, 814-827. [CrossRef] [PubMed]

144. Jansen, D.; Zerbi, V.; Arnoldussen, I.A.; Wiesmann, M.; Rijpma, A.; Fang, X.T.; Dederen, P.J.; Mutsaers, M.P.; Broersen, L.M.; Lütjohann, D.; et al. Effects of specific multi-nutrient enriched diets on cerebral metabolism, cognition and neuropathology in AßPPswe-PS1dE9 mice. PLoS ONE 2013, 8, e75393. [CrossRef]

145. Kawakita, E.; Hashimoto, M.; Shido, O. Docosahexaenoic acid promotes neurogenesis in vitro and in vivo. Neuroscience 2006, 139, 991-997. [CrossRef] [PubMed]

146. Liu, R.Z.; Li, X.; Godbout, R. A novel fatty acid-binding protein (FABP) gene resulting from tandem gene duplication in mammals: Transcription in rat retina and testis. Genomics 2008, 92, 436-445. [CrossRef] [PubMed]

147. Furuhashi, M.; Hotamisligil, G.S. Fatty acid-binding proteins: Role in metabolic diseases and potential as drug targets. Nat. Rev. Drug Discov. 2008, 7, 489-503. [CrossRef] [PubMed]

148. Owada, Y.; Yoshimoto, T.; Kondo, H. Spatio-temporally differential expression of genes for three members of fatty acid binding proteins in developing and mature rat brains. J. Chem. Neuroanat. 1996, 12, 113-122. [CrossRef]

149. Matsumata, M.; Sakayori, N.; Maekawa, M.; Owada, Y.; Yoshikawa, T.; Osumi, N. The effects of Fabp7 and Fabp5 on postnatal hippocampal neurogenesis in the mouse. Stem Cells 2012, 30, 1532-1543. [CrossRef] [PubMed]

150. Owada, Y.; Abdelwahab, S.A.; Kitanaka, N.; Sakagami, H.; Takano, H.; Sugitani, Y.; Sugawara, M.; Kawashima, H.; Kiso, Y.; Mobarakeh, J.I.; et al. Altered emotional behavioral responses in mice lacking brain-type fatty acid-binding protein gene. Eur. J. Neurosci. 2006, 24, 175-187. [CrossRef]

151. Gerstner, J.R.; Perron, I.J.; Riedy, S.M.; Yoshikawa, T.; Kadotani, H.; Owada, Y.; Van Dongen, H.P.A.; Galnte, R.J.; Dickinson, K.; Yin, J.C.P.; et al. Normal sleep requires the astrocyte brain-type fatty acid binding protein FABP7. Sci. Adv. 2017, 3, e1602663. [CrossRef]

152. Takeuchi, Y.; Fukunaga, K. Differential subcellular localization of two dopamine D2 receptor isoforms in transfected NG108-15 cells. J. Neurochem. 2003, 85, 1064-1074. [CrossRef]

153. Shioda, N.; Yamamoto, Y.; Watanabe, M.; Binas, B.; Owada, Y.; Fukunaga, K. Heart-type fatty acid binding protein regulates dopamine D2 receptor function in mouse brain. J. Neurosci. 2010, 30, 3146-3155. [CrossRef] [PubMed]

154. Shioda, N.; Yabuki, Y.; Kobayashi, Y.; Onozato, M.; Owada, Y.; Fukunaga, K. FABP3 protein promotes $\alpha$-synuclein oligomerization associated with 1-methyl-1,2,3,6-tetrahydropiridine-induced neurotoxicity. J. Biol. Chem. 2014, 289, 18957-18965. [CrossRef] [PubMed]

155. Shimamoto, C.; Ohnishi, T.; Maekawa, M.; Watanabe, A.; Ohba, H.; Arai, R.; Iwayama, Y.; Hisano, Y.; Toyota, T.; Toyoshima, M.; et al. Functional characterization of $F A B P 3,5$ and 7 gene variants identified in schizophrenia and autism spectrum disorder and mouse behavioral studies. Hum. Mol. Genet. 2014, 23, 6495-6511. [CrossRef] [PubMed]

156. Yabuki, Y.; Takahata, I.; Matsuo, K.; Owada, Y.; Fukunaga, K. Ramelteon Improves Post-traumatic Stress Disorder-Like Behaviors Exhibited by Fatty Acid-Binding Protein 3 Null Mice. Mol. Neurobiol. 2018, 55, 3577-3591. [CrossRef] [PubMed]

157. Yamamoto, Y.; Kida, H.; Kagawa, Y.; Yasumoto, Y.; Miyazaki, H.; Islam, A.; Ogata, M.; Yanagawa, Y.; Mitsushima, D.; Fukunaga, K.; et al. FABP3 in the Anterior Cingulate Cortex Modulates the Methylation Status of the Glutamic Acid Decarboxylase67 Promoter Region. J. Neurosci. 2018, 38, 10411-10423. [CrossRef] [PubMed] 
158. Amaral, O.B.; Roesler, R. Targeting the NMDA receptor for fear-related disorders. Recent Pat. CNS Drug Discov. 2008, 3, 166-178. [CrossRef]

159. Burgos-Robles, A.; Vidal-Gonzalez, I.; Santini, E.; Quirk, G.J. Consolidation of fear extinction requires NMDA receptor-dependent bursting in the ventromedial prefrontal cortex. Neuron 2007, 53, 871-880. [CrossRef]

160. Lerea, L.S.; Butler, L.S.; McNamara, J.O. NMDA and non-NMDA receptor-mediated increase of c-fos mRNA in dentate gyrus neurons involves calcium influx via different routes. J. Neurosci. 1992, 12, $2973-2981$. [CrossRef]

161. Comai, S.; Gobbi, G. Unveiling the role of melatonin MT2 receptors in sleep, anxiety and other neuropsychiatric diseases: A novel target in psychopharmacology. J. Psychiatry Neurosci. 2014, 39, 6-21. [CrossRef]

162. Doyen, C.; Mighiu, D.; Kaye, K.; Colineaux, C.; Beaumanoir, C.; Mouraeff, Y.; Rieu, C.; Paubel, P.; Contejean, Y. Melatonin in children with autistic spectrum disorders: Recent and practical data. Eur. Child Adolesc. Psychiatry 2011, 20, 231-239. [CrossRef]

163. Huang, F.; Yang, Z.; Liu, X.; Li, C.Q. Melatonin facilitates extinction, but not acquisition or expression, of conditional cued fear in rats. BMC Neurosci. 2014, 15, 86. [CrossRef]

164. Nishiyama, K.; Shintani, Y.; Hirai, K.; Yoshikubo, S. Molecular cloning and pharmacological characterization of monkey MT1 and MT2 melatonin receptors showing high affinity for the agonist ramelteon. J. Pharmacol. Exp. Ther. 2009, 330, 855-863. [CrossRef] [PubMed]

165. Lacoste, B.; Angeloni, D.; Dominguez-Lopez, S.; Calderoni, S.; Mauro, A.; Fraschini, F.; Descarries, L.; Gobbi, G. Anatomical and cellular localization of melatonin MT1 and MT2 receptors in the adult rat brain. J. Pineal Res. 2015, 58, 397-417. [CrossRef] [PubMed]

166. Tian, Y.; Yabuki, Y.; Moriguchi, S.; Fukunaga, K.; Mao, P.J.; Hong, L.J.; Lu, Y.M.; Wang, R.; Ahmed, M.M.; Liao, M.H.; et al. Melatonin reverses the decreases in hippocampal protein serine/threonine kinases observed in an animal model of autism. J. Pineal Res. 2014, 56, 1-11. [CrossRef]

167. Zeng, W.; Mak, D.O.; Li, Q.; Shin, D.M.; Foskett, J.K.; Muallem, S. A new mode of Ca2+ signaling by G protein-coupled receptors: Gating of IP3 receptor Ca2+ release channels by Gbetagamma. Curr. Biol. 2003, 13, 872-876. [CrossRef]

168. Domínguez-Alonso, A.; Valdés-Tovar, M.; Solís-Chagoyán,H.; Benítez-King, G. Melatonin stimulates dendrite formation and complexity in the hilar zone of the rat hippocampus: Participation of the Ca++/Calmodulin complex. Int. J. Mol. Sci. 2015, 16, 1907-1927. [CrossRef]

169. Fukunaga, K.; Yabuki, Y.; Takahata, I.; Matsuo, K. Neurological mechanism and therapeutic strategy for posttraumatic stress disorders. Nihon Yakurigaku Zasshi 2018, 152, 194-201. [CrossRef] [PubMed]

170. Ho, A.K.; Chik, C.L. Modulation of Aanat gene transcription in the rat pineal gland. J. Neurochem. 2010, 112, 321-331. [CrossRef] [PubMed]

171. Walker, D.L.; Ressler, K.J.; Lu, K.T.; Davis, M. Facilitation of conditioned fear extinction by systemic administration or intra-amygdala infusions of D-cycloserine as assessed with fear-potentiated startle in rats. J. Neurosci. 2002, 22, 2343-2351. [CrossRef]

172. Ledgerwood, L.; Richardson, R.; Cranney, J. D-cycloserine facilitates extinction of learned fear: Effects on reacquisition and generalized extinction. Biol. Psychiatry 2005, 57, 841-847. [CrossRef]

173. Attari, A.; Rajabi, F.; Maracy, M.R. D-cycloserine for treatment of numbing and avoidance in chronic post traumatic stress disorder: A randomized, double blind, clinical trial. J. Res. Med. Sci. 2014, 19, 592-598. [PubMed]

174. Shukla, M.; Govitrapong, P.; Boontem, P.; Reiter, R.J.; Satayavivad, J. Mechanisms of Melatonin in Alleviating Alzheimer's Disease. Curr. Neuropharmacol. 2017, 15, 1010-1031. [CrossRef] [PubMed]

175. McFarlane, A.C.; Barton, C.A.; Briggs, N.; Kennaway, D.J. The relationship between urinary melatonin metabolite excretion and posttraumatic symptoms following traumatic injury. J. Affect. Disord. 2010, 127, 365-369. [CrossRef] [PubMed]

176. Agorastos, A.; Linthorst, A.C. Potential pleiotropic beneficial effects of adjuvant melatonergic treatment in posttraumatic stress disorder. J. Pineal Res. 2016, 61, 3-26. [CrossRef] [PubMed]

177. R T Ramirez, R.; Poling, M.I.; deCourten, J.F.; Chamberlain, R.L. Potential positive feedback loop of pineal cyst and posttraumatic stress disorder. Med. Hypotheses 2017, 100, 87-88. [CrossRef] [PubMed] 
178. Alvira, D.; Tajes, M.; Verdaguer, E.; Acuña-Castroviejo, D.; Folch, J.; Camins, A.; Pallas, M. Inhibition of the $\mathrm{cdk} 5 / \mathrm{p} 25$ fragment formation may explain the antiapoptotic effects of melatonin in an experimental model of Parkinson's disease. J. Pineal Res. 2006, 40, 251-258. [CrossRef]

179. Sase, A.S.; Lombroso, S.I.; Santhumayor, B.A.; Wood, R.R.; Lim, C.J.; Neve, R.L.; Heller, E.A. Sex-Specific Regulation of Fear Memory by Targeted Epigenetic Editing of Cdk5. Biol. Psychiatry 2019, 85, 623-634. [CrossRef]

(C) 2019 by the authors. Licensee MDPI, Basel, Switzerland. This article is an open access article distributed under the terms and conditions of the Creative Commons Attribution (CC BY) license (http://creativecommons.org/licenses/by/4.0/). 